\title{
Preparation and Properties of Fractionated Soybean Protein Isolate Films
}

\author{
Yunxiao Wei ${ }^{1}$, Ze'en Huang ${ }^{2}$, Zuolong Yu ${ }^{1,2, * \mathbb{D}}$, Chao Han ${ }^{1}$ and Cairong Yang ${ }^{1}$ \\ 1 Biology and Environment Engineering College, Zhejiang Shuren University, Hangzhou 310015, China; \\ lvwyx@163.com (Y.W.); hanchao96@163.com (C.H.); a15957547059@163.com (C.Y.) \\ 2 Jiangsu Province Key Laboratory of Fine Petrochemical Engineering, Changzhou University, \\ Changzhou 213164, China; hze@cczu.edu.cn \\ * Correspondence: yuzl_2001@zjsru.edu.cn; Tel.: +86-0571-88296959
}

check for updates

Citation: Wei, Y.; Huang, Z.; Yu, Z.; Han, C.; Yang, C. Preparation and Properties of Fractionated Soybean Protein Isolate Films. Materials 2021, 14, 5436. https://doi.org/10.3390/ ma14185436

Academic Editor:

Agnieszka Sobczak-Kupiec

Received: 7 August 2021

Accepted: 13 September 2021

Published: 20 September 2021

Publisher's Note: MDPI stays neutral with regard to jurisdictional claims in published maps and institutional affiliations.

Copyright: (C) 2021 by the authors Licensee MDPI, Basel, Switzerland. This article is an open access article distributed under the terms and conditions of the Creative Commons Attribution (CC BY) license (https:/ / creativecommons.org/licenses/by/ $4.0 /)$.

\begin{abstract}
Soybean protein isolate (SPI) and its four fractionated products (7S globulin, 11S globulin, upper soybean residue, and lower soybean residue) were compared by fabricating films and film liquids. The separation and grading effects, rheological properties of the film liquids, and difficulty in uncovering the films, in addition to the mechanical properties, water vapor permeability, oil permeability, and surface morphology of the films, were investigated. Results showed that the centrifugal precipitation method could be used to produce fractionated products. The 7S and 11S globulin films exhibited better hydrogels at lower shear rates than the other SPIs; however, they were more difficult to uncover. The tensile strength of the graded films decreased by varying degrees. However, the elongation at the break of the upper soybean residue film considerably increased, reaching $70.47 \%$. Moreover, the permeability and surface morphology of the film were enhanced or weakened. The fractionated products, 7S and 11S globulin films, exhibited better performance. Overall, this study provides a basis for the improved development and use of fractioned SPI products.
\end{abstract}

Keywords: soybean protein isolate; packaging film; fractionated separation; mechanical property; permeability

\section{Introduction}

Edible packaging films have recently become a research hotspot because they are environmentally friendly and can be used in food packaging. Currently, the raw materials for preparing edible packaging films mainly include polysaccharides, proteins, and lipids [1-4]. Owing to the different raw materials used in packaging, the performance of different packaging films differs. For example, packaging films based on cellulose, starch, and other polysaccharides show the characteristics of oil resistance, good transparency, and poor mechanical properties. However, packaging films based on proteins exhibit good strength and elasticity, as well as antibacterial properties $[5,6]$. In addition, protein composite films synthesized using different raw materials show improved film performance and enhanced applications $[7,8]$.

The interaction of intramolecular and intermolecular hydrophobic bonds and disulfide bonds form the network structure of soybean protein isolate (SPI) films, which exhibit low gas permeability, excellent mechanical properties, and poor barrier performance [9-11]. The protein content in SPI exceeds $90 \%$ and mainly constitutes 2 S, 7S, 11S, and 15S globulin. Different proteins show different emulsifying abilities and gel strengths [12,13]. Thus, the purification and yield of obtained products vary considerably based on different separation and grading processes of soybeans [14-17].

Fractioned SPI products are mostly used in the food industry. Chiba tofu can be prepared with different degrees of hardness and elasticity by adjusting the ratio of 7S to 11S globulin [18,19]. The foaming properties of SPI are improved using the combined preheat treatment and controlled enzymatic hydrolysis to change the 7S and 11S globulin ratio [20]. 
Based on the comparison of the hepatoprotective effect of SPI, 7S globulin, and 11S globulin, $7 \mathrm{~S}$ shows optimal performance in food processing [21]. Proteins are also directly used in food packaging and coating technology owing to their biodegradability, processability, combination positions, and nontoxicity to food [22,23]. In this study, the separation method of graded SPI, which was optimized by Chong [24], was used to fabricate four products, and the properties of their edible packaging films were compared for precise applications.

\section{Materials and Methods}

\subsection{Preparation of Fractionated SPI Products}

The specific steps for preparing fractionated SPI products based on the literature [24] are as follows: $24 \mathrm{~g}$ SPI (SOYGLOW, Pingdingshan, China) was mixed with $360 \mathrm{~mL}$ water. The $\mathrm{pH}$ was adjusted to 8 using $2 \mathrm{~mol} / \mathrm{L}$ sodium hydroxide solution, and the mixture was mechanically stirred for $1 \mathrm{~h}$. The obtained solution was centrifuged (TDL-5-A, Shanghai Anting Scientific Instrument Factory, Shanghai, China) at $200 \times g$ for 10 min to obtain a precipitate, i.e., the lower SPI residue, and the filtered cake was further filtered using a 200 mesh sieve to obtain the upper SPI residue. To prepare the $11 \mathrm{~S}$ globulin extract, $3 \mathrm{mM}$ sodium sulfite and $5 \mathrm{mM}$ anhydrous magnesium chloride were added to the $11 \mathrm{~S}$ globulin extract. Further, the $\mathrm{pH}$ was adjusted to 5.5 using $2 \mathrm{~mol} / \mathrm{L} \mathrm{HCl}$ solution; then, the mixture was stirred at room temperature for $10 \mathrm{~min}$ and centrifuged at $200 \times \mathrm{g}$ for $10 \mathrm{~min}$. After centrifugation, the $\mathrm{pH}$ of the protein extract was adjusted to 4 using a $2 \mathrm{~mol} / \mathrm{L} \mathrm{HCl}$ solution while stirring for $10 \mathrm{~min}$ and centrifuging at $200 \times g$ for $10 \mathrm{~min}$. The obtained precipitated protein was $7 \mathrm{~S}$ globulin. The two globulin products were then redispersed using deionized water, and the $\mathrm{pH}$ of both solutions was adjusted to 7.5 using a $2 \mathrm{~mol} / \mathrm{L} \mathrm{HCl}$ solution. The final product was obtained by freeze-drying, and four fractionated SPI products were finally obtained.

\subsection{Characterization of Fractionated SPI Products}

Based on the literature [25] and a slight modification, $4 \mathrm{mg}$ samples (SPI, 11S, 7S, lower protein, and upper protein) were weighed and dissolved in a $1 \mathrm{~mL}$ phosphate-buffered solution. After full vortex mixing at $2000 \times g, 20 \mu \mathrm{L}$ of the mixed solution was combined with $5 \mu \mathrm{L}$ of loading buffer $5 \mathrm{X}$ and heated at $100{ }^{\circ} \mathrm{C}$ for $5 \mathrm{~min}$. The samples were prepared and subjected to sodium dodecyl sulfate-polyacrylamide gel electrophoresis (SDS-PAGE) (JY-ECP3000, Beijing JUNYI Electrophoresis Co., Ltd., Beijing, China). SDS-PAGE was performed at a constant voltage of $150 \mathrm{~V}$ using $4-15 \%$ of a denaturing electrophoresis precast glue and stained with Coomassie brilliant blue, decolorized, and scanned.

\subsection{Preparation of SPI Films}

Five films were prepared using $10 \mathrm{~g}$ of SPI or fractioned SPI products as the matrix. As additives, $0.2 \mathrm{~g}$ sodium carboxymethyl cellulose (Shanghai Aladdin Biochemical Technology Co., Ltd., Shanghai, China), 0.12 g carrageenan (Tengzhou Tongda Algae Engineering Technology Co., Ltd., Tengzhou, China), 0.1 g glycerol monodistearate (Shanghai Aladdin Biochemical Technology Co., Ltd., Shanghai, China), and $1.5 \mathrm{~g}$ glycerol (Shanghai Lingfeng Chemical, Ltd., Shanghai, China) were added to $100 \mathrm{~mL}$ deionized water. The $\mathrm{pH}$ was adjusted to 8 using $0.5 \mathrm{~mol} / \mathrm{L}$ sodium hydroxide, and the mixture was stirred at $300 \mathrm{rpm}$ for $30 \mathrm{~min}$ at $80^{\circ} \mathrm{C}$. After vacuum degassing, the film liquids were rolled onto a steel plate, dried in an oven at $60^{\circ} \mathrm{C}$, uncovered, and stored for further use.

\subsection{Characterization of SPI Films}

\subsubsection{Rheology}

The apparent viscosities and shear rate curves of the film liquids were determined using a rheometer (MCR 102, Anton-Paar, Shanghai, China). Measurements were performed at a constant temperature of $80^{\circ} \mathrm{C}$, using a conical plate with a diameter of $50 \mathrm{~mm}$ and an angle of $1^{\circ}$ and the flow curve measurement mode. The shear rate was considered as 
a variable with a range of $0.01-100 \mathrm{~s}^{-1}$, the mode was linear scan, and 50 variable points were selected.

\subsubsection{Contact Angle}

The static contact angle of the fractionated film solutions was measured at $80{ }^{\circ} \mathrm{C}$ to characterize their affinity with the coated sheet. The contact angle between the film solution and the coating plate was measured using a camera device (JC2000D3, Shanghai Zhongchen Digital Technic Apparatus Co., Ltd., Shanghai, China).

\subsubsection{Mechanical Properties}

The sample was cut into strips with a length of $10 \mathrm{~cm}$ and a width of $0.5 \mathrm{~cm}$. The tensile strength $\left(T_{S}\right)$ and elongation at the break $(E)$ of the films were measured (TA.XT Plus, Stable Micro System, London, Britain) along the vertical and horizontal directions using three strips. In total, six parallel samples were measured. The standard distance was $50 \mathrm{~mm}$, and the sampling speed was $100 \mathrm{~mm} / \mathrm{min}$.

$$
T_{S}=F / S,
$$

where $T_{S}$ is the tensile strength (MPa), $F$ is the tensile force of the film $(\mathrm{N})$, and $S$ is the cross-sectional area of the film $\left(\mathrm{m}^{2}\right)$.

$$
E=\left(L-L_{0}\right) / L_{0} \times 100 \%,
$$

where $E$ is the fracture elongation (\%), $L_{0}$ is the standard distance $(50 \mathrm{~mm})$ of the sample $(\mathrm{mm})$, and $L$ is the elongated distance of the specimen fracture $(\mathrm{mm})$.

\subsubsection{Fourier Transform Infrared (FTIR) Spectroscopy}

A small piece of the fractionated SPI film samples was cut and dried. Then, the samples were mixed with $\mathrm{KBr}$ to be pressed into tablets. Fourier transform-infrared (FTIR) spectroscopy (FTIR-650, Bruker, Karlsruhe, Germany) was performed to investigate the influence of the film composition on the film structure. The FTIR spectra were obtained by scanning 64 times at room temperature at a resolution of $4 \mathrm{~cm}^{-1}$ and the wavenumber range of $500-4000 \mathrm{~cm}^{-1}$.

\subsubsection{Permeability}

In a $100 \mathrm{~mL}$ beaker, $50 \mathrm{~g}$ anhydrous calcium chloride (particle size of $2 \mathrm{~mm}$ ) was added. Uniform smooth films without holes or wrinkles were selected. Subsequently, they were measured to determine their thicknesses, sealed at the mouth with molten paraffin, placed in a dryer with $100 \%$ relative humidity, measured at $25^{\circ} \mathrm{C}$, and removed from the dryer, and weighed every $24 \mathrm{~h}$. Three parallel experiments were continuously performed for one week, and the results were presented as the arithmetic mean of each group.

$$
W V P=\Delta m \times d /(A \times t \times \Delta P),
$$

where $W V P$ is the water permeability coefficient $\left(\mathrm{g} \cdot \mathrm{mm} / \mathrm{m}^{2} \cdot \mathrm{d} \cdot \mathrm{KPa}\right), \Delta m$ is the steady mass increment $(\mathrm{g}), d$ is the film thickness $(\mathrm{mm}), A$ is the effective measured area $\left(\mathrm{m}^{2}\right), T$ is the time interval (days) of the measurement, and $\Delta P$ is the vapor pressure difference ( $\mathrm{KPa})$ on both sides of the sample.

The film sealing was measured by placing approximately $5 \mathrm{~mL}$ salad oil in a test tube and then sealing it with the film. The oil was further placed upside down on a filter paper for a week to calculate the average oil permeability coefficients of the three samples.

$$
\text { Poil }=\Delta m \times d / A \times T,
$$


where $P_{\text {oil }}$ is the oil permeability coefficient $\left(\mathrm{g} \cdot \mathrm{m} / \mathrm{m}^{2} \cdot \mathrm{d}\right), \Delta \mathrm{m}$ is the change in the filter paper quality $(\mathrm{g}), d$ is the film thickness $(\mathrm{mm}), A$ is the film area $\left(\mathrm{m}^{2}\right)$, and $T$ is the placement time (days).

\subsubsection{Scanning Electron Microscopy (SEM)}

The surface morphologies of the PSI films were sprayed with gold and observed using scanning electron microscopy (SEM; S-570, Hitachi, Ltd., Tokyo, Japan) at a working voltage of $10 \mathrm{kV}$. Images of the samples were captured after spraying them with gold.

\section{Results and Discussion}

\subsection{Analysis of the Grading Effect}

Fractioned SPI products were obtained using various purity and yield values (Figures 1 and 2 and Table 1) [26]. The lower protein was not dissolved under this electrophoresis condition; however, similar bands were observed for the other samples. This was primarily because different proteins contained different subunits and exhibited different physicochemical properties, while the $\alpha^{\prime}, \alpha$, and $\beta$ subunits of 7S and the acidic and basic subunits of $11 \mathrm{~S}$ globulin were observed $[27,28]$. The SPI showed strong $7 \mathrm{~S}$ and $11 \mathrm{~S}$ globulin compositions. The upper protein yield was different owing to variations in the separation experiments, and there were no products even after modifying the experimental conditions. As more than $90 \%$ of SPI is proteins whose spatial structures and amino acid compositions directly affect the physicochemical properties of protein isolates, the selection of separation methods is crucial [29].

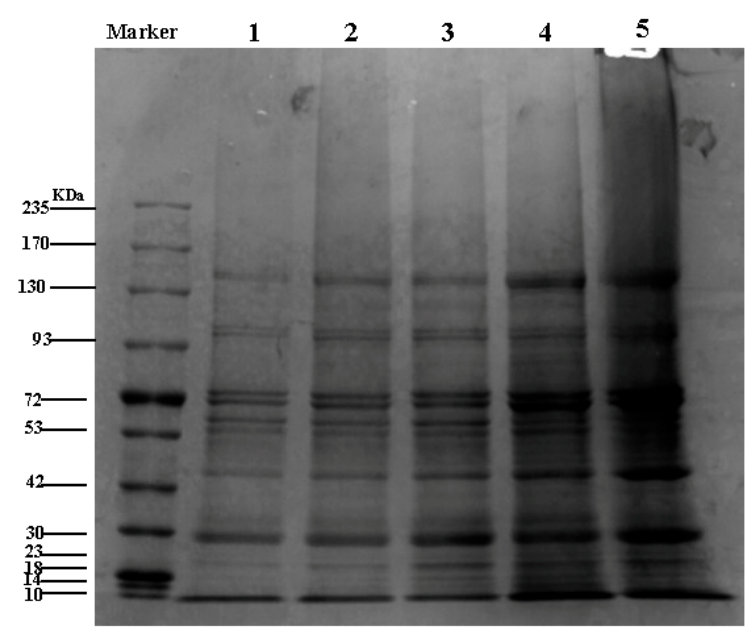

Figure 1. SDS-PAGE of SPI and fractioned products. Marker: the different molecular numbers of proteins: (1) lower protein, (2) upper protein, (3) 11S globulin, (4) $7 \mathrm{~S}$ globulin, and (5) SPI.
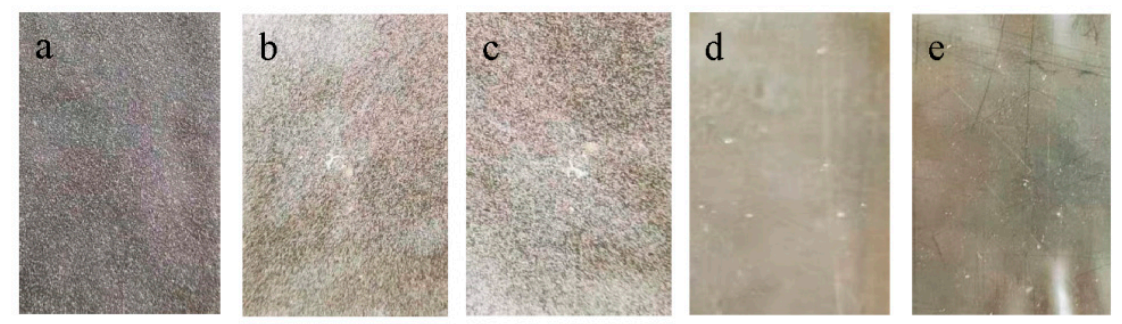

Figure 2. Films of SPI and fractioned products: (a) SPI, (b) lower protein, (c) upper protein, (d) $11 \mathrm{~S}$ globulin, and (e) $7 \mathrm{~S}$ globulin. 
Table 1. Yields and contact angles of the samples.

\begin{tabular}{cccc}
\hline & Weight $(\mathbf{g} / \mathbf{2 4})$ & Yield (\%) & Contact Angle $\left.\mathbf{(}^{\circ}\right)$ \\
\hline SPI & - & - & $47.7 \pm 0.5$ \\
Upper protein & $1.50 \pm 0.26$ & $6.25 \pm 1.10$ & $60.9 \pm 0.6$ \\
Lower protein & $13.96 \pm 1.04$ & $58.19 \pm 4.32$ & $57.0 \pm 0.5$ \\
1SS & $3.22 \pm 0.66$ & $13.42 \pm 2.75$ & $36.2 \pm 0.8$ \\
$7 S$ & $4.45 \pm 0.42$ & $18.57 \pm 1.75$ & $25.7 \pm 0.3$ \\
\hline
\end{tabular}

\subsection{Rheology}

Figure 3 shows the rheological properties of each film solution. The viscosity gradually decreased with the increasing shear rate. However, the $11 \mathrm{~S}$ globulin film solution exhibited a large mutation, and an inflection point was observed when the shear rate was $0.241 \mathrm{~s}^{-1}$. Furthermore, the viscosity of this film solution was lower than that of the SPI film solution. This indicated that the 11S globulin film solution shows a shear-thinning phenomenon and is a non-Newtonian fluid. The gel and emulsification properties of the 7S and 11S globulin film solutions were better than those of the SPI film solution; thus, they achieved high viscosity values at low shear rates. However, the shear resistance of the globular protein decreased at high shear values [30].

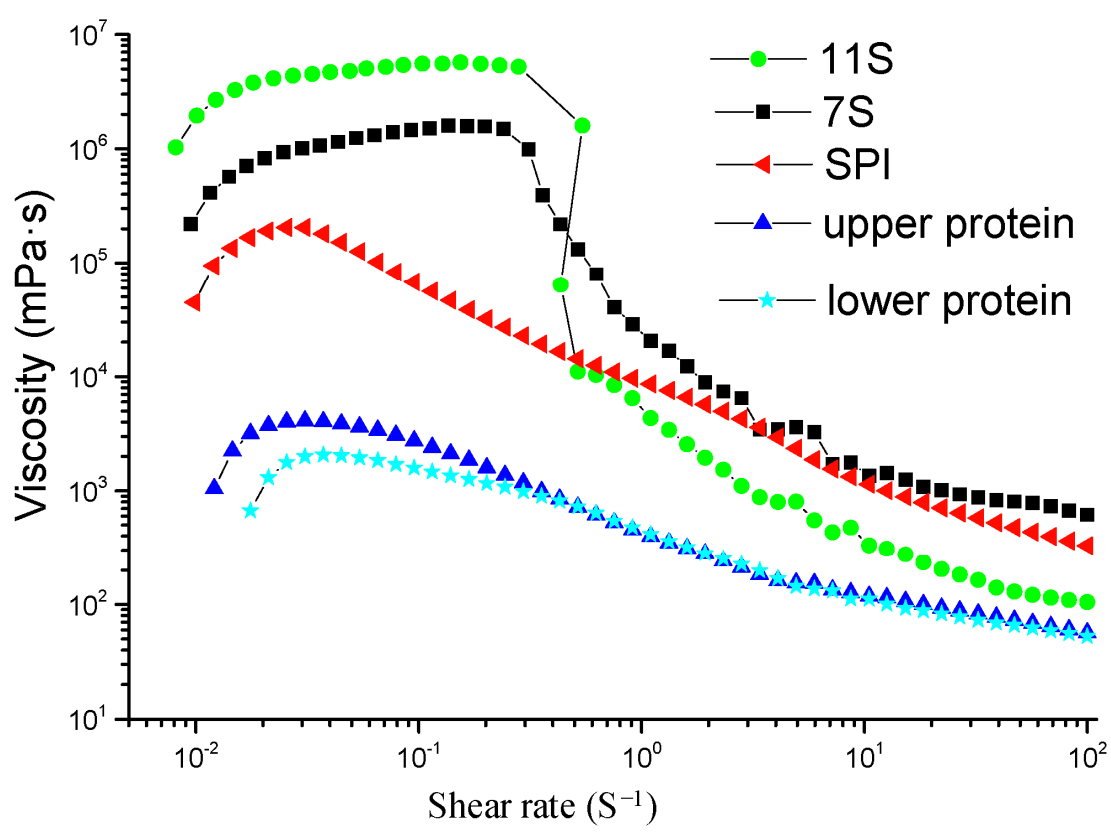

Figure 3. Rheological properties of the film solution of SPI and fractioned products.

\subsection{Contact Angle}

The contact angle between the film solution and the coating plate indicates the difficulty in uncovering the film after its formation [31]. Based on the analysis of the contact angle of the film solutions of SPI and fractioned products (Table 1 and Figure 4), a larger contact angle indicated that the film was easier to uncover. The main reason for differences in the contact angles of the samples was that the hydrophilicity values of different graded proteins were different after gelation and the extent of adhesion to the steel plate was different. For example, 7S globulin had more polar amino acids and showed a smaller molecular gap than others after mixing with additives and close contact with the steel plate [32]. 


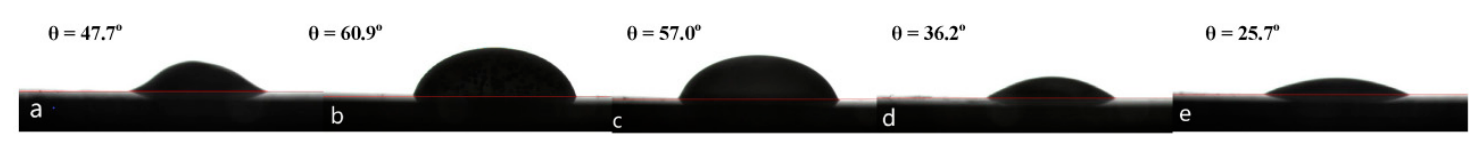

Figure 4. Contact angle of the film solutions of SPI and fractioned products: (a) SPI, (b) upper protein, (c) lower protein, (d) 11S globulin, and (e) 7S globulin.

\subsection{Mechanical Properties}

Figure 5 depicts certain differences in the mechanical properties of the films of SPI and fractioned products. For example, the $T_{S}$ value decreased from $12.94 \mathrm{MPa}$ (SPI film) to 1.22 $\mathrm{MPa}$ (upper protein film), and the $E$ value increased from $2.91 \%$ (SPI film) to $70.47 \%$ (upper protein film). The upper protein film contained more small components than SPI, which promotes plasticization once the film is prepared, allowing molecules to slide more easily and enhancing fracture elongation. However, the mechanical properties of the 7S and 11S globulin films were slightly different. This is primarily because the polar amino acids in proteins promote the plasticizing effect of hydrophilic additives; however, proteins with small molecular weights cannot form complex spatial winding networks, resulting in lower $T_{S}$ than SPI films.

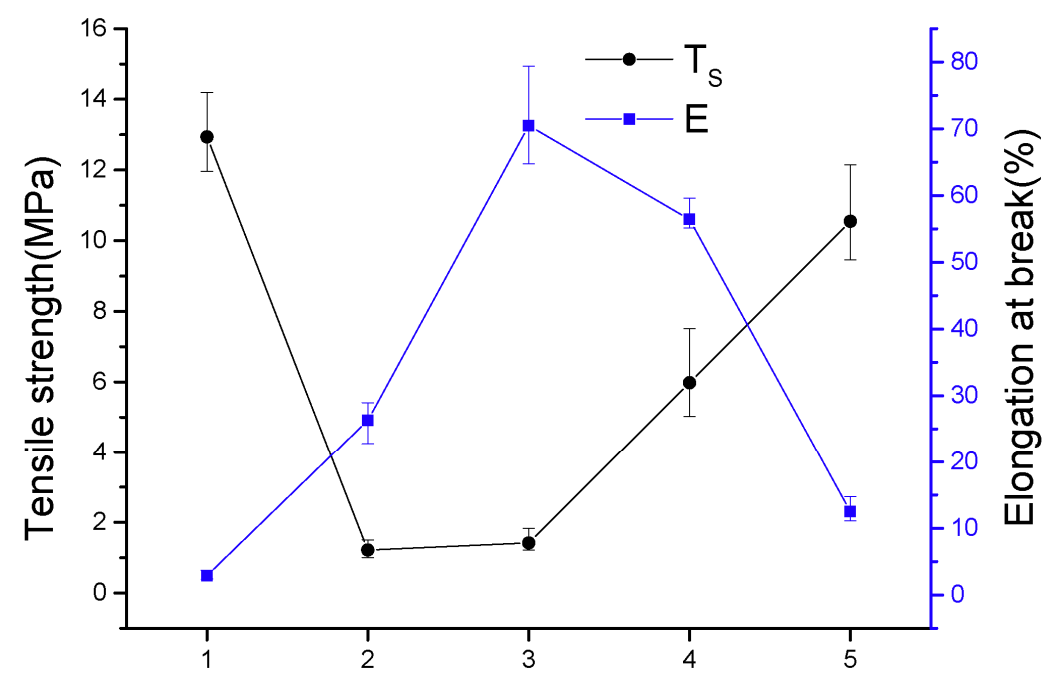

Figure 5. Mechanical properties of the film solutions of SPI and fractioned products: (1) SPI, (2) lower protein, (3) upper protein, (4) 11S globulin, and (5) 7S globulin.

\subsection{FTIR}

Figure 6 shows the FTIR spectra of the five sample films. The experimental results showed similar characteristic absorption peaks of the sample membranes, such as amide I ( $\mathrm{C}=\mathrm{O}$ stretching vibration), amide II ( $\mathrm{N}-\mathrm{H}$ bending vibration), and amide III ( $\mathrm{C}-\mathrm{N}$ and $\mathrm{N}-\mathrm{H}$ stretching vibrations) of the corresponding proteins at 1666,1538 , and $1233 \mathrm{~cm}^{-1}$, respectively [33]. However, the characteristic absorption peaks at $2919 \mathrm{~cm}^{-1}\left(=\mathrm{C}-\mathrm{H}\right.$ and $-\mathrm{NH}^{3+}$ asymmetric stretching vibrations) and $1045 \mathrm{~cm}^{-1}$ (C-H and C-O-H stretching vibrations) were considerably different in terms of the intensity, indicating that the 7S and 11S globulin films had more exposed polar bonds to produce hydrogen bonds. FTIR spectrum analysis further revealed that the precipitation separation approach distinguished the molecular weight of proteins and altered the conformation of the $\alpha$-helical and $\beta$-folding proteins, resulting in unique characteristics of the products. 


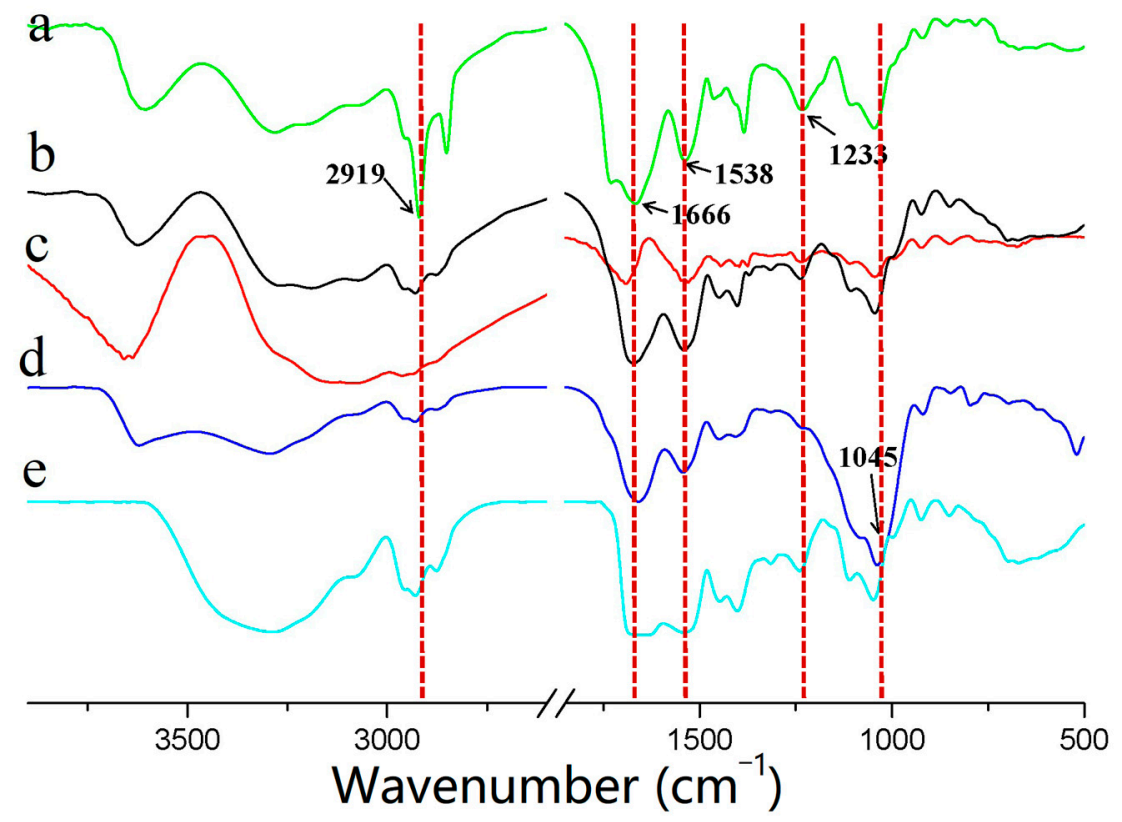

Figure 6. FTIR spectra of the film solutions of SPI and fractioned products: (a) 7S globulin, (b) SPI, (c) upper protein, (d) lower protein, and (e) $11 \mathrm{~S}$ globulin.

\subsection{Gas Permeability}

The permeability of the SPI film was considerably affected after grading (Figure 7). The water vapor permeability of the 11S globulin film was lower than that of the SPI film, whereas those of the other graded protein films were higher than that of the SPI film. However, the oil permeability of the graded protein films decreased, compared with the SPI film, with the $11 \mathrm{~S}$ globulin film showing a decrease from 78.76 to $5.82 \mathrm{~g} \cdot \mathrm{m} /\left(\mathrm{m}^{2} \cdot \mathrm{d}\right)$. As permeability was determined based on the molecular gap and amphiphilicity of membrane components, the permeability of the gas molecules was determined based on the permeation speed [34]. The SPI films with different molecular weights formed a dense, crosslinked structure, which could effectively prevent the passage of water vapor, although their lipophilicity tendency was stronger than those of the other films.

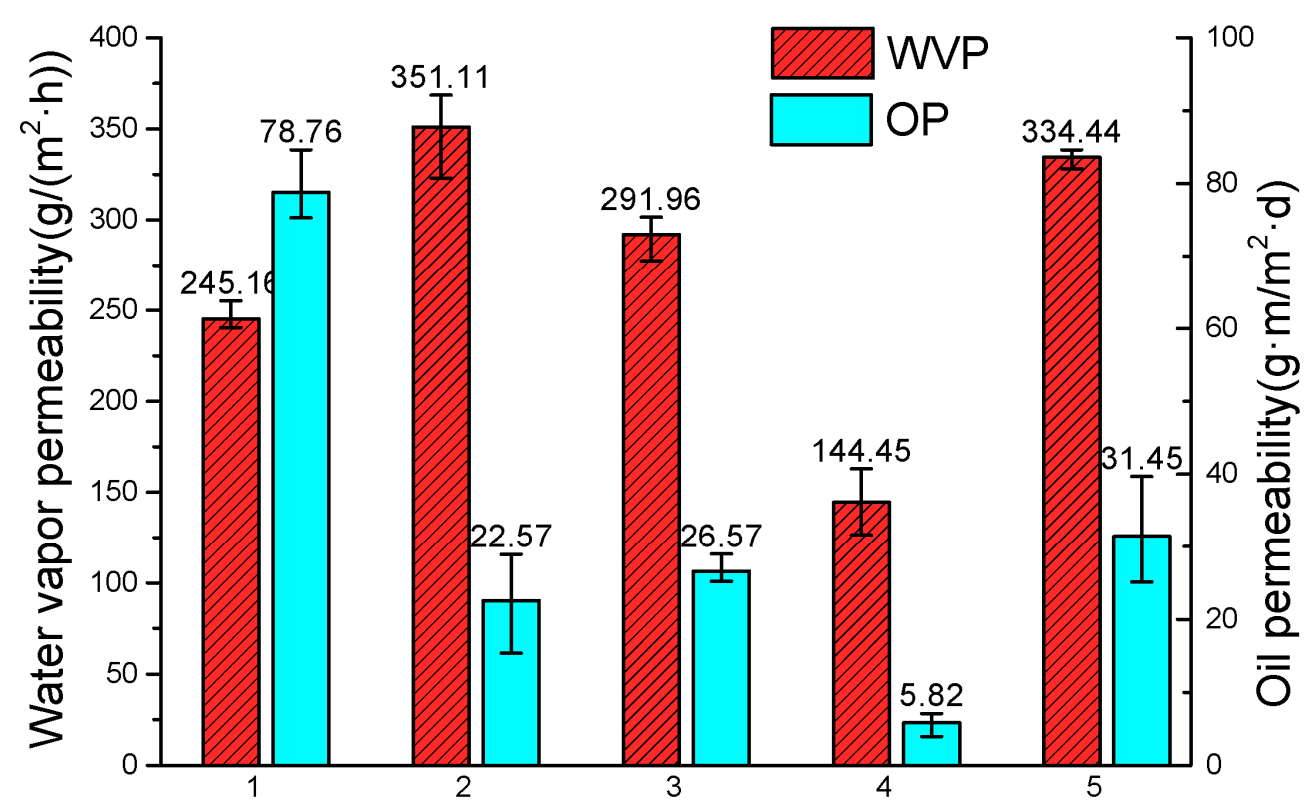

Figure 7. Gas permeability of SPI and fractioned product films: (1) SPI, (2) lower protein, (3) upper protein, (4) 11S globulin, and (5) 7S globulin. 


\subsection{Surface Morphology}

Table 1 and Figure 8 demonstrate that the surface morphologies of the various protein films varied considerably. The upper and lower protein films were coarser than the SPI films, with obvious folds and differently sized bulges. The surface morphologies of the 7S and $11 \mathrm{~S}$ globulin films were smooth and without banded bulges. The poor solubility of the upper and lower proteins mainly resulted in uneven surface morphologies. However, the 7S and 11S globulins with good homogeneity showed excellent emulsification and gelling properties after gelation, which is beneficial for the film extension.
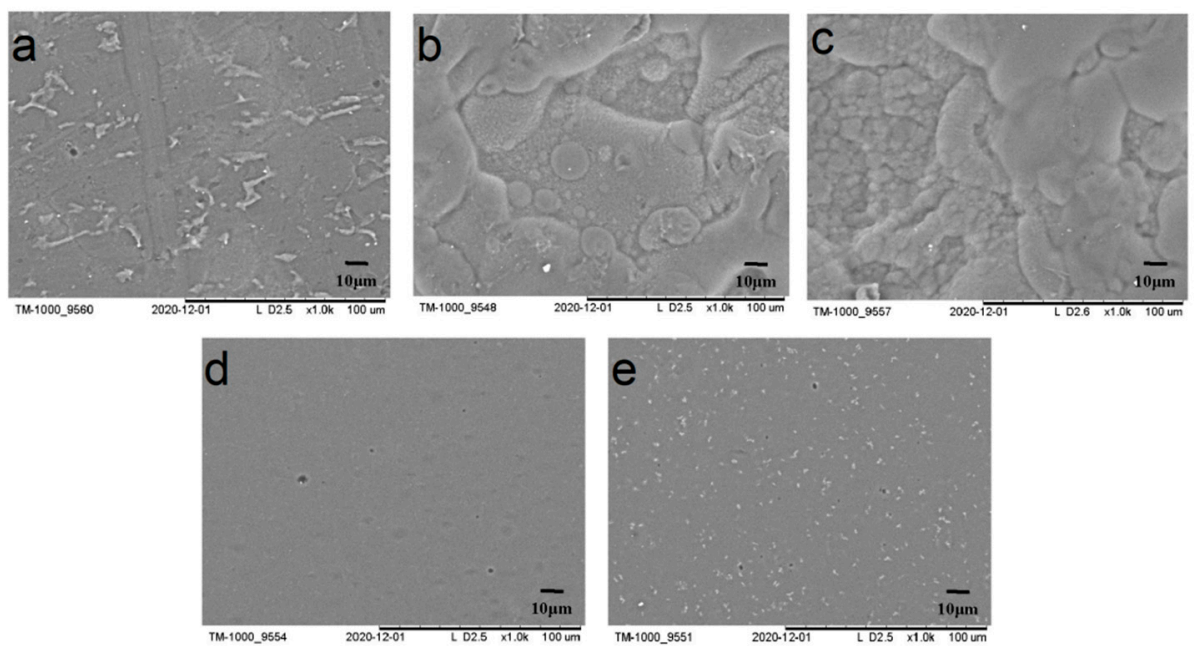

Figure 8. SEM images of SPI and fractioned films: (a) SPI, (b) upper protein, (c) lower protein, (d) $11 \mathrm{~S}$ globulin, and (e) 7S globulin.

\section{Conclusions}

In this study, four fractioned SPIs were synthesized using the optimized centrifugation method. The products exhibited different characteristics from the raw materials. Comparing the film properties of the SPIs and fractioned products, the viscosities of the 7S and 11S globulin film solutions were higher at low shear rates than those of the SPI film solution; however, they rapidly decreased at high shear rates, indicating a non-Newtonian fluid type. The film components with single molecular weights and high hydrophilicity were more difficult to uncover from the steel plate. The $11 \mathrm{~S}$ globulin film showed reduced water vapor and oil permeabilities, from 245.16 and 78.76 to 144.45 and $5.82 \mathrm{~g} \cdot \mathrm{m} /\left(\mathrm{m}^{2} \cdot \mathrm{d}\right)$, respectively. This study indicates that SPI grading can produce food packages or functions for precise development and use.

Author Contributions: This work is part of Z.Y., C.H. and Y.W. designed the research; C.Y. prepared the film and performed some mechanical strength tests; Gas permeability was carried out by Y.W., Z.Y. performed some rheological measurements; FTIR and SEM characterization were performed by Z.H., Z.Y., Y.W. and C.H. discussed the results; Z.Y. and Y.W. wrote the manuscript, which was revised and edited by all the authors. All authors have read and agreed to the published version of the manuscript.

Funding: This research was funded by the Basic Public Welfare Research Program of Zhejiang Province (LGN21C200019 and LGF21C200001), the Jiangsu Province Key Laboratory of Fine Petrochemical Engineering (KF2104) and Young Doctor Innovation Program (2019QC21) of Zhejiang Shuren University.

Institutional Review Board Statement: Not applicable.

Informed Consent Statement: Not applicable.

Data Availability Statement: All data are freely available. 
Acknowledgments: The authors would like to acknowledge financial support from the Basic Public Welfare Research Program of Zhejiang Province (LGN21C200019 and LGF21C200001), the Jiangsu Province Key Laboratory of Fine Petrochemical Engineering (KF2104) and Young Doctor Innovation Program (2019QC21) of Zhejiang Shuren University.

Conflicts of Interest: The authors declare no conflict of interest.

\section{References}

1. Han, J.H. (Ed.) Innovations in Food Packaging, 2nd ed.; Elsevier: Amsterdam, The Netherlands, 2014.

2. Lipatova, I.; Yusova, A.; Makarova, L. Fabrication and characterization of starch films containing chitosan nanoparticles using in situ precipitation and mechanoactivation techniques. J. Food Eng. 2021, 304, 110593. [CrossRef]

3. Zhang, Y.; Li, T.; Zhang, H.; Zhang, H.; Chi, Y.; Zhao, X.; Li, H.; Wen, Y. Blending with shellac to improve water resistance of soybean protein isolate film. J. Food Process. Eng. 2020, 43, 13515. [CrossRef]

4. Rangaraj, V.M.; Rambabu, K.; Banat, F.; Mittal, V. Effect of date fruit waste extract as an antioxidant additive on the properties of active gelatin films. Food Chem. 2021, 355, 129631. [CrossRef]

5. Yuan, G.; Jia, Y.; Pan, Y.; Li, W.; Wang, C.; Xu, L.; Wang, C.; Chen, H. Preparation and characterization of shrimp shell waste protein-based films modified with oolong tea, corn silk and black soybean seed coat extracts. Polym. Test. 2020, 81, 106235. [CrossRef]

6. Aziz, S.G.-G.; Almasi, H. Physical Characteristics, Release Properties, and Antioxidant and Antimicrobial Activities of Whey Protein Isolate Films Incorporated with Thyme (Thymus vulgaris L.) Extract-Loaded Nanoliposomes. Food Bioprocess Technol. 2018, 11, 1552-1565. [CrossRef]

7. Su, J.-F.; Huang, Z.; Yuan, X.-Y.; Wang, X.-Y.; Li, M. Structure and properties of carboxymethyl cellulose/soy protein isolate blend edible films crosslinked by Maillard reactions. Carbohydr. Polym. 2010, 79, 145-153. [CrossRef]

8. Jensen, A.; Lim, L.-T.; Barbut, S.; Marcone, M. Development and characterization of soy protein films incorporated with cellulose fibers using a hot surface casting technique. LWT 2015, 60, 162-170. [CrossRef]

9. Chiralt, A.; González-Martínez, C.; Vargas, M.; Atarés, L. Edible films and coatings from proteins. In Proteins in Food Processing; Elsevier BV: Amsterdam, The Netherlands, 2018; pp. 477-500.

10. Ramos, O.; Reinas, I.; Silva, S.I.; Fernandes, J.; Cerqueira, M.; Pereira, R.N.; Vicente, A.; Poças, M.D.F.; Pintado, M.E.; Malcata, F.X. Effect of whey protein purity and glycerol content upon physical properties of edible films manufactured therefrom. Food Hydrocoll. 2013, 30, 110-122. [CrossRef]

11. Gennadios, A.; Brandenburg, A.H.; Weller, C.L.; Testin, R.F. Effect of $\mathrm{pH}$ on properties of wheat gluten and soy protein isolate films. J. Agric. Food Chem. 1993, 41, 1835-1839. [CrossRef]

12. Xiaoquan, Q.J. Comparative studies on functional properties of soy protein fractions. J. Chin. Cereals Oils Assoc. 2010, 25, 26-30.

13. Guo, Q.Q.; Zhang, N.; Zhao, X.H. Evaluation of functional properties of soybean graded protein. Sci. Technol. Food Ind. 2006, 27, 74-76.

14. Nagano, T.; Hirotsuka, M.; Mori, H.; Kohyama, K.; Nishinari, K. Dynamic viscoelastic study on the gelation of $7 \mathrm{~S}$ globulin from soybeans. J. Agric. Food Chem. 1992, 40, 941-944. [CrossRef]

15. Wu, S.; Murphy, P.A.; Johnson, L.A.; Reuber, A.M.A.; Fratzke, A.R. Simplified Process for Soybean Glycinin and $\beta$-Conglycinin Fractionation. J. Agric. Food Chem. 2000, 48, 2702-2708. [CrossRef]

16. Deak, N.A.; Johnson, L.A. Fate of Phytic Acid in Producing Soy Protein Ingredients. J. Am. Oil Chem. Soc. 2007, 84, 369-376. [CrossRef]

17. Teng, Z.; Liu, C.; Yang, X.; Li, L.; Tang, C.; Jiang, Y. Fractionation of Soybean Globulins Using Ca2+ and Mg2+: A Comparative Analysis. J. Am. Oil Chem. Soc. 2009, 86, 409-417. [CrossRef]

18. Zheng, L.; Wang, Z.; Kong, Y.; Ma, Z.; Wu, C.; Regenstein, J.M.; Teng, F.; Li, Y. Different commercial soy protein isolates and the characteristics of Chiba tofu. Food Hydrocoll. 2021, 110, 106115. [CrossRef]

19. Wang, X.; Luo, K.; Liu, S.; Zeng, M.; Adhikari, B.; He, Z.; Chen, J. Textural and Rheological Properties of Soy Protein Isolate Tofu-Type Emulsion Gels: Influence of Soybean Variety and Coagulant Type. Food Biophys. 2018, 13, 324-332. [CrossRef]

20. Liang, G.; Chen, W.; Qie, X.; Zeng, M.; Qin, F.; He, Z.; Chen, J. Modification of soy protein isolates using combined pre-heat treatment and controlled enzymatic hydrolysis for improving foaming properties. Food Hydrocoll. 2020, 105, 105764. [CrossRef]

21. Liu, W.W.; Ye, Y.H.; Hu, J.; Nie, S.P.; He, H. Hepatoprotection of soybean protein isolate, and 7S, 11S proteins. J. Chin. Cereals Oils Assoc. 2016, 31, 32-36.

22. Mihalca, V.; Kerezsi, A.; Weber, A.; Gruber-Traub, C.; Schmucker, J.; Vodnar, D.; Dulf, F.; Socaci, S.; Fărcas, A.; Muresan, C.; et al. Protein-Based Films and Coatings for Food Industry Applications. Polymers 2021, 13, 769. [CrossRef] [PubMed]

23. Chen, H.; Wang, J.; Cheng, Y.; Wang, C.; Liu, H.; Bian, H.; Pan, Y.; Sun, J.; Han, W. Application of Protein-Based Films and Coatings for Food Packaging: A Review. Polymers 2019, 11, 2039. [CrossRef]

24. Chong, L. Mechanism of Soy Protein Fractionation and Separation. Ph.D. Thesis, South China University of Technology, Guangzhou, China, 2009.

25. Huihua, H.; Kongrong, G.; Qianchu, G.; Hanhua, L. SDS-PAGE patterns of soybean, defatted soy bean and soybean protein isolates. Food Sci. 2000, 21, 15-19.

26. Tian, K.; Guan, J.; Shao, Z.Z.; Chen, X. Structural and functional study of soybean protein isolation. Prog. Chem. 2008, 20, 565-573. 
27. Maruyama, N.; Salleh, M.R.M.; Takahashi, K.; Yagasaki, K.; Goto, H.; Hontani, N.; Nakagawa, A.S.; Utsumi, S. StructurePhysicochemical Function Relationships of Soybean $\beta$-Conglycinin Heterotrimers. J. Agric. Food Chem. 2002, 50, 4323-4326. [CrossRef]

28. Katsube, T.; Maruyama, N.; Takaiwa, F.; Utsumi, N. Food protein engineering of soybean proteins and development of soy-rice. In Engineering Crop Plants for Industrial End Uses; Shewry, P.R., Napier, J.A., Davis, P., Eds.; Portland Press: London, UK, 1998; pp. 65-76.

29. Marcone, M.F.; Kakuda, Y.; Yada, R.Y. Salt-soluble seed globulins of various dicotyledonous and monocotyledonous plants-I. Isolation/purification and characterization. Food Chem. 1998, 62, 27-47. [CrossRef]

30. Perrechil, F.A.; Ramos, V.A.; Cunha, R. Synergistic Functionality of Soybean 7S and 11S Fractions in Oil-in-Water Emulsions: Effect of Protein Heat Treatment. Int. J. Food Prop. 2014, 18, 2593-2602. [CrossRef]

31. Yu, Z.; Rao, G.; Wei, Y.; Yu, J.; Wu, S.; Fang, Y. Preparation, characterization, and antibacterial properties of biofilms comprising chitosan and $\varepsilon$-polylysine. Int. J. Biol. Macromol. 2019, 141, 545-552. [CrossRef] [PubMed]

32. Yang, A.; Deng, H.; Zu, Q.; Lu, J.; Wu, Z.; Li, X.; Tong, P.; Chen, H. Structure characterization and IgE-binding of soybean 7S globulin after enzymatic deglycosylation. Int. J. Food Prop. 2018, 21, 186-197. [CrossRef]

33. Wang, H.; Wang, L. Developing a bio-based packaging film from soya by-products incorporated with valonea tannin. J. Clean. Prod. 2017, 143, 624-633. [CrossRef]

34. Vásconez, M.B.; Flores, S.; Campos, C.A.; Alvarado, J.; Gerschenson, L.N. Antimicrobial activity and physical properties of chitosan-tapioca starch based edible films and coatings. Food Res. Int. 2009, 42, 762-769. [CrossRef] 